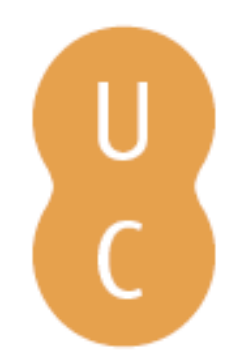

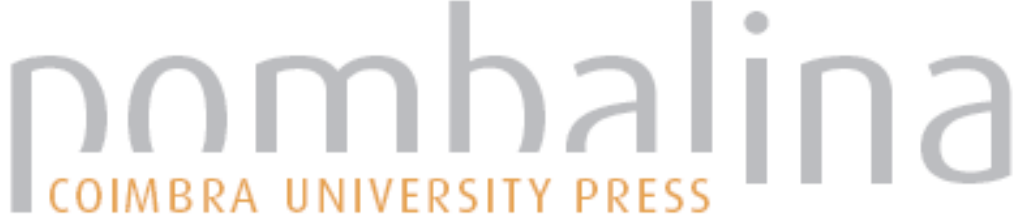

\section{Considerações sobre a máquina narrativa}
Autor(es):
Babo, Maria Augusta
Publicado por: Imprensa da Universidade de Coimbra
URL persistente:
URI:http://hdl.handle.net/10316.2/41344
DOI:
DOI:https://doi.org/10.14195/978-989-26-1324-6_3

Accessed : $\quad$ 26-Apr-2023 14:55:14

A navegação consulta e descarregamento dos títulos inseridos nas Bibliotecas Digitais UC Digitalis, UC Pombalina e UC Impactum, pressupõem a aceitação plena e sem reservas dos Termos e Condições de Uso destas Bibliotecas Digitais, disponíveis em https://digitalis.uc.pt/pt-pt/termos.

Conforme exposto nos referidos Termos e Condições de Uso, o descarregamento de títulos de acesso restrito requer uma licença válida de autorização devendo o utilizador aceder ao(s) documento(s) a partir de um endereço de IP da instituição detentora da supramencionada licença.

Ao utilizador é apenas permitido o descarregamento para uso pessoal, pelo que o emprego do(s) título(s) descarregado(s) para outro fim, designadamente comercial, carece de autorização do respetivo autor ou editor da obra.

Na medida em que todas as obras da UC Digitalis se encontram protegidas pelo Código do Direito de Autor e Direitos Conexos e demais legislação aplicável, toda a cópia, parcial ou total, deste documento, nos casos em que é legalmente admitida, deverá conter ou fazer-se acompanhar por este aviso.

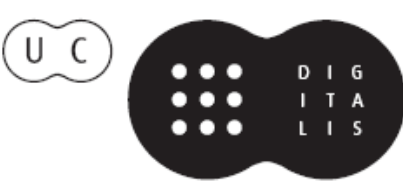





\title{
CONSIDERAÇÕES SOBRE A MÁQUINA NARRATIVA
}

\author{
Maria Augusta Babo \\ FCSH - Universidade Nova de Lisboa
}

\section{Uma introdução}

Porque falamos de narrativa? Porque contamos histórias? Porque designamos a maior parte dos processos de significação como narrativos?

A narrativa é de tal maneira abrangente dos regimes semióticos, dos fazeres discursivos, das práticas significantes que ela se tornou um termo de extensão máxima e de compreensão mínima, pelo menos na sua utilização pelo discurso do senso comum. Para além de se verificar uma distinção entre narrativa entendida no seu sentido mais restrito e outras formas de discursivização como o diálogo, a argumentação, a descrição, entre outras, dir-se-ia, num primeiro momento, que a narrativa é uma máquina de textualização do mundo e da experiência. É desta afirmação que partimos e à qual iremos chegar tentando demonstrar esse estatuto da narrativa e o seu funcionamento. Mais precisamente, a narrativa tem uma relação estreita com o tempo. Ela organiza, configura a temporalidade do e no humano. A narrativa é, vista por este prisma, a máquina semiótica por excelência, não dependendo do regime semiótico em que elabora, que pode ser imagético, ou outro. Ela opera a um nível macro e não frásico, por um lado, e é uma estruturação subjacente à manifestação 
discursiva, por outro. Assim, a narrativa romanesca não difere da narrativa fílmica ou da narrativa em $\mathrm{BD}$ já que os mecanismos semióticos que a compõem são os mesmos. Tratar-se-á, em qualquer dos casos, de organizar a temporalidade inerente à organização das ações entre elas.

Considerada por alguns especialistas como uma estrutura inata, a elaboração narrativa está patente no próprio desenvolvimento do sujeito falante que, quase simultaneamente à aquisição da linguagem, tende a narrativizar a experiência da forma mais elementar e simples; um primeiro grau de narrativização que articula o relato através da preposição - depois, e depois, e depois... - numa sucessão infinita. Se ainda não se está perante uma organização complexa da temporalidade que a narrativa, nas suas formas mais elaboradas, fornece, deparamo-nos com um primeiríssimo movimento, espontâneo, de ordenação temporal, produtor de efeitos de sentido que extravasam a própria sucessividade, como se verá adiante. Narrar é humano e será talvez a narração (o relato ou o discurso rapporté), e não tanto a faculdade de linguagem, aquilo que distingue o simbólico, no ser humano, relativamente a outros códigos existentes em várias espécies animais. É que, relativamente ao discurso no presente e em presença, caso do diálogo, quer no relato simples - o discours rapporté - quer na narrativa, uma organização mais complexa e elaborada, existe um diferimento do dito e, sobretudo, uma suspensão do regime constativo, performativo, ou, como o designou Deleuze, do regime de palavra de ordem, existentes no primeiro caso. Quer isto dizer que passamos dos regimes discursivos da transmissão de informação, da criação de efeitos imediatos, da ação à sua representação; não à representação direta do mundo, não é disso que se trata em nenhuma narrativa, mas a um diferimento da ação. Narrar é já contar um discurso, uma voz, uma ordem, um ato de fala. Narrar um ato de fala é retirar-lhe a sua atualidade, a sua performatividade, a sua capacidade de intervir diretamente na situação de comunicação. 
Narrar é diferir, distanciar, tornar indireto o que no discurso é direto. Essa passagem, essa operação gramatical, em que consiste a própria gramatização da experiência, é aquela mesma que executa todo o sujeito falante, como o entendeu Benveniste, quando passa do regime atual do discurso direto - evento, fala, ordem, ação em palavras - para a sua narração, indireta, despessoalizada, desfazada da situação de discurso e, portanto, não atuante nela: diferida. A narração por oposição ao discurso, para o linguista francês, dá-se exatamente por uma modificação do campo da deixis, pela passagem do sujeito da enunciação - eu - ao sujeito do enunciado - ele/ela que acarreta o deslocamento do tempo - agora - e do espaço - aqui. Deslocamento do sujeito que passa do seu estatuto de pessoa-subjetiva a um estatuto de não-pessoa (Benveniste, 1966: 231). Narrar é distanciar-se do tempo e do espaço, do aqui e do agora, deslocando, nesse distanciamento, o sujeito para fora de si; alter-ando, objetualizando o sujeito. Narrar é inscrever o sujeito como objeto (da ação). Daí que uma diferença intransponível se estabeleça entre discurso e narrativa. A sua incoincidência advém deste deslocamento espacio-temporal, de um diferimento que colocará a narrativa, sempre, fora do tempo da história e o narrador com ela, num mundo onde já não pode intervir. A narrativa nega o presente, mesmo quando ela aí se coloca como estratégia discursiva. Será sempre, de cada vez, um presente embraiado, quer isto dizer, uma enunciação enunciada, como the chama Greimas.

Ora, este distanciamento que a narrativa como máquina cria relativamente ao real, ao vivido, à experiência, não é outra coisa senão a própria condição de todo o texto ao operar uma semiotização do mundo. Na verdade, textualizar o mundo, textualizar a experiência, a ordem do vivido, é criar um investimento significante por sobre os fenómenos; é aplicar-lhes uma máquina de semiotização, quer dizer, é constituir um todo de sentido através da articulação de enunciados que se tornam, enquanto totalidade, autónomos e, nessa medida, 
diferidos. A textualização liberta-se da sua ancoragem ao contexto. Resiste ao contexto, desliga-se, por essa capacidade de mîse-en-distance, para funcionar como um todo de sentido. Um olhar sobre o mundo que cria mundo. A narrativa não será senão a máquina mais perfeita, mais acabada de textualização do real.

Máquina do tempo, a narrativa assenta num complexo mecanismo de organização da temporalidade. Tempo e narrativa estão, pois, indissoluvelmente ligados, sendo a própria máquina narrativa o dispositivo por excelência de conferição de uma organização ao tempo vivido, ao tempo cósmico, ao tempo convencional, até.

A remissão da temporalidade para a ordem da linguagem é levada a cabo por Agostinho, naquilo que ficou conhecido pela conceção de um tempo interior. Na verdade, essa interiorização do tempo só é possível dado que a própria linguagem o organiza para o sujeito do discurso. Assim, Agostinho ao colocar-se a questão ontológica sobre a temporalidade (o que é o tempo? Questão aparentemente ingénua na sua formulação - 2001: 299) dá-se conta que revém à linguagem a função de o organizar para o sujeito, ou, dito de outro modo, que o sujeito advém na linguagem porque é esta que o coloca: o sujeito é na linguagem. E o presente é, por excelência, o tempo que opera essa coincidência, essa fusão entre a linguagem e o sujeito. Embora, e nisso reside a própria aporia da temporalidade, o presente seja, de cada vez, evanescente.

Agostinho formula assim as três dimensões do presente na sua projeção interior: «o espírito espera [expectat] e está atento [adtendit] (este verbo lembra a intentio praesens) e ele lembra-se [meminit]" (2001: 314). O tempo é assim uma afeção, tensiva ou distendida, conforme se mede a sua extensão ou a sua intenção e estas, no interior da própria linguagem. Há, pois, três operações do espírito e são elas que medem o tempo: a expetativa, a (a)tenção e a memória. A narração implica distensão e projeta-se na e pela memória: são as confissões que se distendem por todo o seu passado que constituem 
o próprio exercício de narrativização do vivido, assim legado à humanidade inaugurando uma configuração narrativa que criará mesmo um género literário.

Ao entender a autobiografia como máquina narrativa pretende-se salientar a existência de um dispositivo narrativo que condensa mecanismos vários para constituir um todo homogéneo centrado no próprio. Essa máquina narrativa usa processos ficcionais, isto é, todo um conjunto de procedimentos figurativos da ordem do imaginário, mas inseridos no quadro de uma articulação narrativa. Na verdade, a autobiografia, considerada nesta perspetiva, participa do testemunho de vida mas também da ficção, no sentido de elaboração imaginária, da verdade do sujeito emergindo em configurações variadas, imagens manipuladas, deturpadas até, possivelmente. É, porém, a narrativa que subsume toda essa heterogeneidade e lhe dá uma configuração temporal e lhe confere sentido.

\section{A organização narrativa}

O termo "narrativa" está de tal forma vulgarizado que ele ocorre como sinónimo de discurso, como foi referido. No entanto, a narrativa é uma máquina bem precisa que integra mecanismos próprios e desempenha funções determinadas na conferição de sentido. Desde já se afirma que a máquina narrativa é a mais poderosa máquina de conferição de sentido ao tempo e, consequentemente, ao acontecimento. Entender como ela funciona será importante para determinar a sua especificidade e para a desinserir do discurso em geral, de qualquer ato discursivo, como geralmente é empregada.

A narrativa é, como foi afirmado, um distanciamento no tempo. Pôr à distância, organizar na distância do tempo, na ausência do sujeito; fazer o mundo vir à ordem da linguagem, semiotizar ou gramatizar o mundo, como se poderá formular nas diferentes perspetivas de 
análise. É, portanto, e antes de mais, um dispositivo de diferimento, não coincidente com "a presente instância do discurso", como designou Benveniste o ato discursivo. Narrativizar será uma operação semiótica que, ao mesmo tempo que distancia o sujeito do real vivido, da res, lhe atribui sentido e, portanto, uma legibilidade própria e comum. É assim que B. Lamizet entende a semiotização do acontecimento, por exemplo (2006).

Então, narrar começa por ser articular ações umas com as outras; dar-lhes uma sequência, dispô-las por ordem de ocorrência. A este primeiro nível corresponde a compulsão intuitiva à narração que todo o sujeito falante, desde a sua aprendizagem e aquisição de competência, elabora, de uma forma muito simples, a que já aludimos: a organização cronológica das ocorrências. A articulação de um antes e um depois é uma primeira operação de narrativização dos acontecimentos, das pequenas situações do quotidiano de que o sujeito faz a experiência de apropriação. Ela constitui a própria estruturação dos acontecimentos nas suas posições relativas, através da ordenação temporal. O tempo que flui ininterruptamente, segmenta-se em ações e é ordenado cronologicamente. Inerente a esta primeira operação está já a capacidade de segmentação, de tornar descontínuo o que foi vivido como contínuo e de lhe conferir uma dimensão significante, ao atribuir sujeitos às ações, ao nomeá-las como motores da narrativa, ao atribuir-lhes consequências ou objetos sobre que recaem. Designa-se por sequencialidade esta ordenação do Khronos. E, ao contrário do que precipitadamente se considera, não constitui a única operação nem sequer a mais importante da máquina narrativa. Pode definir-se esta operação como uma operação de relato que, compondo a complexa máquina de narrar não a esgota por certo. U. Eco deu como exemplo aos seus alunos um pequeno relato da sua chegada à Universidade de Bolonha para dar aulas. Perante a sequencialidade das ações de rotina por ele contadas, os estudantes, atónitos, perguntaram-se qual a razão de ser de tal relato. 
É que, na verdade, nada nele justificava a narrativa. O que falta a um relato para ser narrativa, portanto? Diríamos, com Umberto Eco, que falta um acontecimento marcante. É o acontecimento marcante que fará de um relato uma narrativa, isto é, que permite uma mudança de registo com implicações estruturantes.

A narrativa envolve então a transformação de predicados durante um processo. A narrativa é mesmo esse processo de transformação que conduz de um antes a um depois, tal como por exemplo a gramática sémio-narrativa da Escola de Paris a determina. De uma forma genérica, a narrativa envolve um fazer transformador de um estado inicial de disjunção entre Sujeito e Objeto para um estado final de conjunção. $\mathrm{O}$ fazer transformador opera esse processo, quer no sentido positivo, da conjunção, quer no sentido negativo ou disfórico, da disjunção. Mas, em qualquer dos casos, é a transformação a grande viragem que executa o próprio processo narrativo, invertendo os conteúdos.

Há uma organização lógico-temporal que suporta a textualidade. A esta organização chamou a Escola de Paris sémio-narativa. A estruturação textual é transfrásica e de ordem semiótica, não linguística. Os modelos narratológicos mais alargados vieram explicar em que consiste a coesão e a coerência textuais em termos estruturais. Só esta estruturação interna permite colocar o sentido como um todo que extravasa a soma dos enunciados. A narratividade, de um lado, e a configuração narrativa, do outro, permitem o tratamento da organização textual, conferindo, no entanto, à dimensão temporal uma função e estatuto distintos segundo a perspetiva adotada. Por oposição à configuração narrativa que elabora a temporalidade intrínseca ao mythos, a estrutura narrativa é de natureza lógica e, por conseguinte, acrónica. Quer dizer que a semiótica está interessada em analisar a constituição do sentido, exercendo uma espécie de ocultação do cultural, da tradição, pelo estrutural, pelo lógico, enquanto a hermenêutica através da inteligência narrativa procura 
definir a configuração da experiência e da temporalidade a ela inerente pela narrativa.

Sejam quais forem as abordagens metodológicas que a narrativa convoca, inúmeros modelos narratológicos que a produção estruturalista e pós-estruturalista levou a cabo, há algo que atravessa todas as perspetivas narratológicas e ainda a hermenêutica narrativa: a existência de um conflito, de um desequilíbrio, de uma suspensão, de um confronto, de uma polémica - polemos - quer ela seja, segundo Greimas e Courtés (1986), cognitiva, pragmática ou tímica (relativa aos humores). Para Greimas a narrativa é, por excelência, o lugar da polémica e do conflito: o lugar de uma "concordância discordante", na expressão de Paul Ricoeur que remete para uma dialética da narrativa. Sem essa reviravolta no curso das ocorrências não há verdadeiramente narrativa. É esse inesperado que "modifica o curso da história" num sentido imprevisível, mas que, para se constituir como componente da narrativa, tornar-se "um fator de concordância" (Gilbert, 2001: 60). Acrescente-se, obviamente, e da sua resolução. Enfim, seja o que for que constitua o nó-da-intriga será da ordem do acontecimento. Do acontecimento como rutura; do acontecimento como acontecimento disruptivo, sem o qual não se vê como pode haver narrativa, em que é que a máquina narrativa assenta para o ser.

É de realçar que a narrativa exige uma unidade temática, unidade essa que será mais da ordem da unidade das ações, assumidas por um só sujeito. Há um denominador comum entre drama e narrativa, a unidade de ação. A Poética de Aristóteles coloca bem a especificidade do que aqui se joga, quer no drama, quer na narrativa. A narrativa tem a capacidade forte de tecer-se à volta de uma ação central, de estabelecer um enredo, por exemplo, aquilo que na Poética é referido como o mythos e que Ricoeur traduz por nó-da-intriga. Tomando o termo de empréstimo a Platão (Ricoeur, 1983: 62), o mythos em Aristóteles reúne simultaneamente a composição dramática e a composição diegética. A tragédia é representação de ação, é 
uma construção, encontra-se intrinsecamente ligada à fabricação do mythos, a ação encarada como um todo orgânico. A representação tem como finalidade, na tragédia, a instauração de uma ordem de causalidade na ação, um ordenamento do mythos - o nó da intriga - que permite falar já de uma operação de universalização por sobre o acontecimento singular. A atividade mimética no seu sentido original, mimesis, é, pois, uma operação de criação de um muthos universal. O fazer representativo afasta-se tanto mais da cópia, do representado, quanto a representação implica um redimensionamento da ação e uma re-configuração do particular no geral. É esse o sentido do trágico aristotélico. Quer isto dizer que a representação como atividade poiética confere uma coerência orgânica à sucessão puramente temporal das ações que permite fazer sair estas, enquanto organizadas, da pura contingência do acontecimento real para as inscrever numa ordenação geral, numa verdade que é sobretudo um ordenamento segundo o necessário. A diegese, por seu turno, constitui esse diferimento da narração que, em vez de nos aparecer de frente, no momento da sua representação, nos é contada, em diferido, por um narrador, uma instância que elabora e medeia a ação, que possui um ponto de vista, que se inscreve, no plano mais apagado de todos, como uma instância ausente. É, propriamente, a história (Reis e Lopes, 1991). O nó-da-intriga tudo convoca e tudo emaranha; a narrativa, por seu lado, deslindará este emaranhado de ações que se oferecem como resistência ao sentido, enigma.

Se, portanto, concebermos como estruturante da narrativa o acontecimento disruptivo, se o considerarmos o punctum da narrativa, então deparamo-nos com a verdadeira aporia da narrativa tal como Ricoeur a entende. As narrativas canónicas - e há que distinguir entre a narrativa como texto concreto, preciso, nomeável (o conto, a novela, o romance) e a narrativa como máquina ou gramática de texto - apresentam, todas elas: um princípio ou situação inicial, uma transformação, núcleo, ou nó da intriga e uma situação final ou 
desenlace. Ricoeur define o nó da intriga como essa organização de acontecimentos que transformam o relato em história e constituem a narrativa. Este nó da intriga é a própria articulação lógica dos acontecimentos que, ao mesmo tempo, destroem a situação inicial, que a invertem, a desestabilizam. Ora, o que acontece na estruturação narrativa, o que a máquina narrativa vem conferir à sequencialidade temporal de acontecimentos ligados por uma temática, assumidos pelos actantes, é justamente uma organização poderosa dessas ações de modo a trazê-las, mesmo se invertidas, a um desenlace. O desenlace é o telos da narrativa e ao mesmo tempo aquilo que enclausura o nó da intriga resolvendo-o. Ora, o mythos que constitui a narrativa possui uma organização lógica que dá consistência à própria narrativa, que é, até, a própria finalidade da máquina narrativa. Essa coerência lógica é subsumida pela causalidade narrativa. Quer isto dizer que os acontecimentos que se sucedem na manifestação narrativa estão ligados mais fortemente, do ponto de vista lógico, por uma articulação causal. Aquilo que na Antiguidade era aforisticamente formulado na célebre máxima: post hoc, ergo propter hoc, que se traduz, mantendo a concisão latina, por: depois disto, então por causa disto. A expressão latina dá-nos a dimensão da forte articulação que a máquina narrativa traz ao encadeamento cronológico dos acontecimentos propondo-nos a chave dessa sucessividade. Se B acontece depois de A então, deveremos concluir que A provocou B ou que A é a causa de B. Esta transposição da ordem da sequência cronológica para a ordem da lógica causal está de tal maneira enraizada no senso comum que ela explica logo por si qualquer acontecimento que surja como irrupção na rotina temporal. Dito de outro modo ainda, a conferição de uma causa a um acontecimento (disruptivo) vem trazer-lhe um imediato princípio de explicação e, portanto, de regularização desse mesmo acontecimento, rebatendo-o na sua sequencialidade. Essa conferição de causalidade é a própria ação da máquina narrativa; a máquina narrativa empresta uma lógica 
causal à sequência (arbitrária ou contingente) de acontecimentos de modo a absorver o acontecimento, justamente inexplicável, porque saindo fora da rotina, da sucessão, de novo à sua explicação. O que a máquina narrativa opera ao jogar por sobre os acontecimentos, essa lógica da causalidade, subsumindo-a na sequencialidade temporal, é precisamente, trazer a exceção à regra, trazer o disruptivo ao causal, trazer o contingente ao necessário. A tal universalização que elabora por sobre o acontecimento real para o devolver já como semiotizado. É nessa semiotização e nesse distanciamento do real que ele ganha uma “consistência simbólica” (Lamizet, 2006: 280) e é apropriável então pela comunidade, é universalizável.

$\mathrm{Na}$ verdade, esta função primordial da narrativa ultrapassa a própria lógica causal para vir assumir, na teoria narrativa de Paul Ricoeur, um estatuto determinante no conceito de configuração narrativa, que constitui a dimensão hermenêutica mais profunda da própria máquina narrativa como máquina de conferição de sentido (narrativo) ao acontecimento (disruptivo). A configuração narrativa é uma avaliação global do fenómeno. Olhada pela perspetiva da mise-en-intrigue, a configuração narrativa subsume uma oposição, à primeira vista inconciliável, entre temporalidade, na vertente de duração, e acontecimento. Uma é organizada, linear e contínua, o outro disruptivo, fragmentário, descontínuo. Esta aporia dá lugar, na análise ricoeuriana, à trilogia Temps et Récit (1983, 1984, 1985), que trabalha a articulação entre acontecimento e temporalidade narrativa nas suas diversas configurações, desde a narrativa de ficção, passando pela narrativa da história, até à constituição da refiguração como "um regresso" à experiência, agora do leitor.

É que a configuração narrativa da temporalidade elabora por sobre a heterogeneidade dos tempos e dos acontecimentos. Para Ricoeur, a noção de configuração narrativa permite resolver a descontinuidade inerente ao acontecimento. A força disruptiva do acontecimento vemlhe da sua própria natureza. A mîse-en-intrigue tem, justamente, por 
função inverter esse "efeito de contingência" (Ricoeur, 1990: 169) em "efeito de necessidade ou de probabilidade" que o ato configurador exerce. É o que afirma Ricoeur desenvolvendo a sua tese: "A inversão do efeito de contingência em efeito de necessário produz-se no próprio âmago do acontecimento..." (1990: 170).

Note-se, contudo, que a contingência do acontecimento, que faz dele precisamente acontecimento, e o seu carácter necessário na narrativa não são da mesma ordem. Esta passagem da contingência ao necessário dá-se na elaboração après coup, na diegese, isto é, no próprio ato de contar, de "pôr em intriga", porque narrar será trazer um olhar organizado àquilo mesmo que surgiu como disrupção. A proposta de uma inteligência narrativa ricoeuriana vai no sentido de conceder à narrativa essa finalidade hermenêutica última que é a da conferição de sentido ao acontecimento, isto é, uma organização temporal que, articulando o acontecimento num conjunto de ações, lhe propõe uma causalidade; the devolve um telos, uma finalidade, um sentido. Apesar das surpresas, das peripécias, das contingências da história, uma narrativa orienta-se para uma finalidade, tem uma função teleológica que é assumida pela conclusão e que procede à clausura textual (narrativa), até porque, na sua estruturação, a narrativa pode ler-se invertida, de trás para frente, mostrando a ligação intrínseca de cada sequência narrativa ao todo e à sua finalidade.

A narrativa como dispositivo de mediação é, desde logo, conferidora de sentido através da organização de uma temporalidade que se encontra, a partir de então, ligada, isto é, indissociável. Daí que o acontecimento, disruptivo em si mesmo, se converta em ação necessária à prossecução da intriga. O ato configurante, que é, para todos os efeitos, um ato semiótico, leva a cabo uma compreensão deste todo articulado pois, à medida que a narrativa se forma e vai articulando ações, ela também lhes confere um dado ponto de vista, o do narrador, e até, muitas vezes, uma avaliação. É o que acontece explicitamente na fábula como género narrativo onde essa avaliação 
final nos é dada como "moral da história". Nessa medida então, a narrativa extravasa da sua clausura textual para vir conferir uma compreensão e uma interpretação ao acontecimento agora narrativizado. Na sua expressão mais aberta, a narrativa comporta um juízo de natureza reflexiva. Ora, justamente, a noção de configuração aplicada à narrativa vai Ricoeur buscá-la a L. O. Mink:

\begin{abstract}
ao compreendermos em conjunto os acontecimentos em atos configurativos, a operação narrativa tem o carácter de juízo e mais precisamente de juízo reflexivo no sentido kantiano do termo: contar e seguir uma história é já 'refletir sobre' os acontecimentos com vista a englobá-los em totalidades sucessivas (Ricoeur, 1980: 5).
\end{abstract}

A narrativa será, portanto, antes mesmo ou para além do seu registo ficcional, um ato judicativo. O narrado incorpora um juízo que, ao mesmo tempo, se distancia do mundo e o interpreta, avalia esse mundo que ele próprio fabrica no simbólico. E esta operação advém de uma especificidade muito própria à narrativa, a de facultar a passagem do dizer ao contar. Se o ato discursivo se dá no corpo do sujeito, pela fala, pela presença, a narrativa como escrita opera já uma cesura. Digamos, com Bernard Lamizet: "Enquanto fazemos corpo com a fala, enquanto dizemos através da nossa voz ou ouvimos pelas nossas orelhas (...), escrever o acontecimento ou lê-lo é encontrar-se confrontado com a materialidade de um significante que nos é exterior, o da escrita" (Lamizet, 2006: 121) A narrativa é esse exterior objectualizante que opera a mediação entre a "mutabilidade" da vida e a "continuidade da história".

A procura ricoeuriana de constituição de um si-mesmo, distinto do eu-mesmo, assenta na importância dada aos processos de mediação e à temporalidade. A identidade narrativa é disso o exemplo, por excelência. O si-mesmo constrói-se a partir da mediação narrativa. Esta 
"função mediadora que a identidade da personagem exerce entre os polos da mesmidade e da ipseidade /.../" (1990: 176) pode ser conferida pela própria literatura. Aquilo que está indissoluvelmente ligado à vida é, portanto, a narrativa. E, nessa medida, para Ricoeur, a noção de identidade confunde-se com a de identidade narrativa. Por aqui se entende a função configuradora da narrativa na constituição dessa entidade que é a identidade ipse - a ipseidade. O eu torna-se um sujeito do fazer; identidade do ipse, no percurso narrativo. Uma identidade como que objetivada e investida de sentido. É a narrativa, na sua inscrição textual, que vem configurar, não o eu do discurso, simples deítico, mas o eu capaz de subsumir uma temporalidade organizada: a subjetividade mais ou menos fictícia que atravessa e se organiza numa vida contada. A literatura dá forma e também espessura à subjetividade, pela capacidade que tem de conferir existência e exterioridade à interioridade do sujeito; mas, ainda pela capacidade que possui de o fazer atravessar o tempo. A sua existência na escrita é a condição mesma da sua própria existência ipse. E isto, quer a narrativa seja ou não ficcional. Se há uma ficcionalidade operativa inerente à máquina narrativa, essa ficcionalidade não deixa, no entanto, de se revelar a própria veritas do sujeito. O texto narrativo é essa instância produtora de subjetivação; devolve-nos um mundo interpretado e é dele que a subjetividade emerge, não como origem mas como resultado.

\section{A narrativa da história ou a história como narrativa}

Na medida em que narrar é uma prática de mediação simbólica que começa por fundar o discurso comum, a constituição do campo da narrativa faz-se a partir de uma homologia entre a narrativa ficcional e a narrativa da história. Em ambos os casos dá-se o facto de a operação configurante ser a mîse-en-intrigue, na medida em que a inteligência narrativa, enquanto "síntese temporal do heterogéneo" 
acontece em tanto para a ficção quanto para o domínio do factual (Ricoeur, 1984: 230-233). Para Ricoeur, porém, as dissimetrias, assentam na questão da verdade. Assim, as fronteiras entre configuração - organização do sentido - e refiguração - aproximação à referência, ao ato - não foram nem podem ser derrubadas. O que distingue ambas as narrativas está para além da própria organização interna, situando-se na transcendência do texto. Trata-se, neste entendimento da questão, da confrontação entre o mundo do texto e o mundo de vida do leitor. Ora, na dimensão já mais englobante que lhe confere Ricoeur, pode dizer-se até que também a narrativa ficcional tem uma pretensão à verdade, pois originária ou não do imaginário, ela confere uma certa verdade do sujeito, do tempo, da ação.

Na sua dimensão puramente formal, isto é, na própria máquina de produção da mîse-en-intrigue, a análise semiótica vem mostrar uma engrenagem homóloga às narrativas ficcionais e não-ficcionais. Não é, portanto, no plano da configuração narrativa que encontramos dissimetrias entre narrativas de ficção e de não-ficção. A fronteira entre sentido e referência, ou, nos termos de Ricoeur, entre configuração e refiguração, não será transposta, como o próprio afirma, "desde que o mundo da obra seja uma transcendência imanente ao texto", isto é, na medida em que a referência (de base) deixar de ser a realidade para passar, tanto num como no outro caso, a ser o mundo que o texto cria, ou o "quase-mundo do texto”. De notar, ainda com Ricoeur (1984: 233), que a ficção elabora de forma praticamente ilimitada desdobramentos temporais. Ora, o desafio do sentido e da referência só é atingido no horizonte de uma teoria da leitura que determine essa refiguração, a integração do texto no "mundo de vida do leitor". Como assinala ainda o autor, a singularidade da sua proposta vem do facto de ela "não separa[r] a pretensão à verdade da narrativa de ficção daquela inerente à narrativa histórica, e esforça[r]-se por compreender uma em função da outra” (Ricoeur, 1984: 234). 
Se a distinção entre ficção e história parece inabalável, segundo a taxinomia dos géneros literários clássicos, na verdade ela é muito ténue ou, diríamos, demasiado complexa, pois justamente a ancoragem ao real nunca é direta nem da ordem da simples transparência. E, se é verdade que podemos afirmar que a narrativa da história obedece, no entanto, à máquina configuradora, capaz de temporalizar, de organizar, de religar ações, também não é menos verdade que a narrativa ficcional é um documento insubstituível no estudo, por exemplo, dos costumes, das práticas sociais, dos códigos de classe, ou dos perfis psicológicos e antropológicos de uma qualquer época da história. Nessa medida, o ficcional não é menos verdadeiro que o factual. O romance, quer ele seja realista ou naturalista mas, por que não, o romântico, é exemplo da ficcionalidade narrativa em que o grau de elaboração é tão apurado que serve o discurso da história com uma fidelidade e complexidade espantosas. O ficcional pode, nesta perspetiva, ser lido como documental, testemunho. Por outro lado ainda, desde o momento em que cabe à operação de refiguração, a tarefa de ancoragem do "mundo do texto" no horizonte da leitura, toda a narrativa ficcional ou não, despertará, por certo, uma verdade da leitura, um confronto que toca ou interpela a verdade.

Associar a narrativa da história à ficção será, portanto, uma identificação precipitada e inexata? De facto, a máquina narrativa, sendo constituída por um conjunto de procedimentos em análise, tem necessariamente uma relação, a definir, com o seu referente. Toda a narrativa, sendo produção de sentido sobre a experiência ou o campo do imaginário, releva, necessariamente de uma relação complexa com o real a que faz apelo, donde parte ou que produz. O equívoco da teoria da representação que elege o realismo como o seu modo de ser é pensar a linguagem como transparência (Foucault, 1966: 133), uma espécie de adesão do simbólico, ou até a sua aderência ao real. O que a perspetiva semiótica na sua visão englobante vem mostrar é que essa transparência é ilusória, já que todo o representante gera 
semiose que opacifica necessariamente a sua relação ao objeto. Donde, não há, no simbólico, representação pura, mas constante produção semiósica, cabendo mesmo aos próprios objetos e à matéria bruta, quando sobre eles recai o olhar do observador, tornarem-se regimes semiósicos.

No caso do regime textual, quer o documento, quer a ficção são sempre já da ordem da mediação e dos seus dispositivos e, portanto, factos semióticos, passíveis de interpretação. Em que consiste ela? Outras tantas questões se nos levantam:

Como se articula a narrativa com o mundo? Pode a narrativa referir o mundo? De que forma? Neste ponto, as teorias da narrativa divergem, ainda.

Representação vai buscar a sua génese ao termo grego mimesis; mas é da tradução latina que ela ganha um sentido fixo mais restrito, a imitatio. Entendida na sua perspetiva binária, a representação dirá então simplesmente a relação com o referente, o objeto da realidade que é suposto ser representado. Texto e realidade, texto e mundo foram, desde sempre, remissões indiscutíveis, baseadas num empirismo primário. No que respeita uma teoria da narrativa, coube à Nova Poética ter questionado esta relação que a tradição tornou inquestionável, em nome da semiose que se efetua dentro do texto ou de texto para texto. Admitindo que o texto gera sentido e que este sentido não está absolutamente desligado do mundo de textos que o contextualizam, a perspetiva que a Nova Poética ofereceu ao entendimento alargado da textualidade como um longo e variado texto em processo, é o da intertextualidade, que veio substituir a representação mimética e integrar o texto numa relação de reenvios constantes entre textos.

A tese da autorreferencialidade envolve toda a teoria literária, desde Jakobson a Barthes. Contra a referencialidade da literatura, por exemplo, Barthes contrapunha os "códigos de representação", que lhe permitiam definir a referencialidade como "ilusão referencial" 
ou ainda como "efeito de real". A verosimilhança assentando não na adequação ao real mas ao texto comum, uma adequação ao texto circulante do senso comum. Para a corrente pós-estruturalista, então, a referencialidade narrativa é subsumida pela intertextualidade, dado que nenhum texto se cria do nada, ele insere-se, antes, num movimento de interligação, de redite, e a referência torna-se assim uma questão de ideologia, de evocação ou remissão a uma formação discursiva prévia, comum a um grupo, a uma comunidade cultural, etc. Nesta perspetiva, como bem sintetizou Umberto Eco, o referente é, antes, a biblioteca.

Ricoeur, não admitindo a transparência narrativa baseada numa lógica simplista da representação nem abolindo a referência, subsumida pela intertextualidade abrangente, traça uma teoria geral do discurso narrativo, de ficção e histórico. Ambos contribuem, embora de forma diferente, para a mesma "condição histórica" que caracteriza a humanidade. Ambos desempenham a mesma tarefa hermenêutica de compreensão do mundo e do sujeito nele inserido, histórica e culturalmente.

O estatuto do referente é, portanto, muito particular dado que esta noção em Ricoeur não releva exclusivamente do âmbito do fora-de-texto mas é reintroduzida na narrativa, na medida em que constitui um seu efeito (Saudan, 1991). A referencialidade emerge como incontornável na narrativa da história. Nela aparece uma categoria não tratada que é o real passado e que se impõe questionar. Ora, trabalhando as noções de real e de irreal, como categoria do ficcional, não do lado da sua oposição intransponível que é do domínio dos factos, mas do lado dos seus efeitos, verifica-se que elas se aproximam. É já uma articulação entre ambas, essa transcendência na imanência que caracteriza o conceito ricoeuriano de "mundo do texto". Projetando a noção de representância nos efeitos de real, mais do que na análise da sua proveniência, a teoria ricoeuriana remete-os para o horizonte do leitor, esse "mundo efetivo do leitor" (1985: 149) 
que é o seu garante. A forma de contornar e de aproximar ambas as categorias narrativas é então resolvida e reabsorvida pela referência, sempre movente e sempre historizada, constituída pelo mundo do leitor. Há nesta visão um cruzamento necessário entre narrativa de ficção e narrativa da história. Esta abordagem só ganha plenamente sentido se admitirmos que a perspetiva narratológica de Ricoeur transcende o puro texto para desembocar numa filosofia do sujeito e na determinação da identidade que não é outra senão a identidade narrativa, referida atrás. Identidade essa, referente a um indivíduo ou a um coletivo: povo, sociedade, comunidade.

Focando agora mais de perto o texto da história, há a considerar que este integra o dispositivo narrativo de que a própria ficção se serve e parece ser-lhe exclusivo. Em primeiro lugar assinale-se a unidade estrutural da narrativa histórica: a história, embora explicativa, como o são as ciências naturais, é profundamente narrativa, já que narrar é, do ponto de vista semiótico, um modo de explicação dos factos, na medida em que nos fornece as suas conexões internas. Depois, o próprio conceito de intriga integra o discurso da história, na medida em que há uma trama entre as ações ou elas deixariam de ter qualquer pertinência no contexto da história. É que um acontecimento histórico deve participar na elaboração da intriga. Intriga é justamente o conceito que opera a ponte com a ficção. Uma história sustenta-se pela conclusão e pela expectativa que cria, não dedutível mas pelo menos previsível ou quando muito aceitável. E, tal como a ficção, a história também se compõe de acontecimentos episódicos, não estruturantes ou configuradores de sucessão que vêm enriquecer e dar espessura à narrativa.

A disciplina da história exige do observador um distanciamento e uma perspetiva explicativa/compreensiva que desenham uma espécie de meta-narrativa englobante. David Carr (1991: 205/212) pergunta-se se a narrativa não será, no quadro de uma hermenêutica como a de Ricoeur, ao mesmo tempo um dispositivo epistemológico e uma 
instância ontológica. É que ela exerce essa função de compreensão hermenêutica que capta o sentido através do exercício de contar. Tal como a narração, a compreensão de si tem uma dimensão temporal. E daí, segundo Carr, que não seja possível separar a vida, da narrativa dessa mesma vida, já que esta mantém a ligação entre os tempos passado, presente e futuro contra a ameaça da fragmentação, da incoerência e da dissolução. A conclusão que retira é de que uma comunidade se constitui em sujeito da experiência através de um conjunto de ações comuns, projetadas num passado, num presente e num futuro. Encontramos esta mesma conceção em Ricoeur, a possibilidade de uma identidade narrativa aplicada a um sujeito coletivo. Para David Carr, a proposta de Ricoeur, no quadro das ciências humanas, tal como a de Gadamer, reconhece um fundo ontológico da atividade hermenêutica que procura descrever e entender (1991: 209). A questão tal como ela se coloca, então, deverá ser, ao mesmo tempo, epistemológica e ontológica, na medida em que a narrativa para além de ser um instrumento cognitivo é ainda da ordem da compreensão hermenêutica.

O entendimento que tem Ricoeur da narrativa faz desta, a um tempo, uma atividade do conhecimento e uma realidade histórica. Ao ser, num primeiro momento, configurado pela narrativa, o tempo é, posteriormente, refigurado, na medida em que ele faz parte integrante da receção futura sobre acontecimentos passados e constitui propriamente o nosso conhecimento do passado. Se a narrativa possui uma natureza epistemológica, uma vez que ela é capaz de um enfoque sobre o real e nos dá o conhecimento do passado, a sua natureza ôntica traduz-se nessa capacidade de participar na constituição da história futura. Recebida pelos leitores, essa narrativa contribuirá para a constituição da realidade histórica. A ontologização consiste propriamente nesse "modo de existência narrativo" (Carr, 1991: 206). Forma conceptual de entender o passado, a narrativa funda a própria epistemologia da história, não se confinando, portanto, a 
uma noção simplesmente literária. Assim, na perspetiva da filosofia analítica de A. Danto e de L. O. Mink (convocados por David Carr), ela é um "instrumento cognitivo", i. é, "um modo de compreensão", uma forma conceptual de entender o passado. Do ponto de vista ontológico, a narrativa só se aplica à história "na medida em que ajuda a esclarecer a natureza da sociedade”. Uma comunidade só pode constituir-se em sujeito da experiência, de ações comuns, se tem a consciência de um passado, de um presente e de um futuro comuns" (1984: 212).

Ainda uma outra dimensão da narrativa da história salientada por Ricoeur é o facto de a história como narrativa ser uma escrita. A "escrita da história" é uma extensão escritural que extravasa ou gera a própria máquina narrativa, conferindo-lhe um estilo, um enquadramento cultural, no sentido em que toda a narrativa integra e se integra nos modos canónicos da narrativa e nos seus géneros. Esses modos são tantas estruturas quantas as formas culturais codificadas e institucionalizadas. E permitem determinar efeitos de sentido, trágico, epopeico, satírico, e não propriamente determinar a natureza intrínseca do "material a organizar (Ricoeur, 1983: 238).

Há efetivamente uma questão que emerge da narrativa da história e que foi determinada e formulada pelo pensamento francês à volta desse fazer que é propriamente a escrita da história, quer com Michel de Certeau, quer com Paul Veyne e Foucault. Do ponto de vista da estrutura narrativa, quer a ficção quer a história pertencem à mesma categoria, o que aproxima a história da literatura (Ricoeur, 1983: 228). Ora, estas posições, que a escola francesa toma como válidas, permitem colocar a questão da ligação entre a ficção e a história ou entre a narrativa ficcional e, empregando uma expressão menos feliz, a narrativa factual. Tal como a define Paul Veyne, uma das figuras marcantes da epistemologia contemporânea da história, a história não seria senão uma "narrativa verídica" (Ricoeur, 1983: 239), composta de acontecimentos que são colocados em intriga, configurados. Esta 
ambição de verdade que age na narrativa da história estaria suspensa deliberadamente, segundo Ricoeur, na ficção (1983: 315).

Paul Veyne através da análise à abordagem histórica de Foucault, teoriza precisamente sobre o fazer história (1971). Compara a história ao romance, porque ela organiza, seleciona e simplifica, em suma, ela é uma verdadeira mîse-en-intrigue. A história é reconstituição, não diretamente a partir do acontecimento, não se reporta diretamente ao referente mas indiretamente, a partir das suas marcas. Ora, essa reconstituição indireta cria um efeito ou cria como efeito a ilusão da reconstituição direta. $\mathrm{O}$ acontecimento é de uma natureza fugidia, não é físico nem é uma substância; é antes um processo onde se misturam "substâncias em interação com homens e coisas" (Veyne, 1971: 51). Por outro lado, a história constitui-se com base no documento, não no acontecimento. Nessa medida, também, ela distingue-se da narrativa jornalística ou biográfica. A história lida com documentos que asseguram uma relação referencial: da ordem do escrito, da imagem, do património, ou do registo em geral; compara documentos, relaciona-os, discute a sua fundamentação e integra-os numa trama narrativa que os configura. A história é essa mesma configuração que traz uma perspetiva, um juízo, um ponto de vista. E, por isso, não há a História mas histórias. Cada acontecimento histórico é, portanto, suscetível de ser objeto de múltiplas narrativas que o vão configurar sobre diferentes ângulos. Não há História mas textos narrativos que elaboram o passado coletivo de forma organizada, interpretando os factos pelas ligações que a narrativa estabelece ou não entre eles. O real, enquanto passado, será assim um manancial inesgotável de narrativas em devir. E essa potência do real dá-nos também o teor da sua distância e da sua diferença relativamente a cada uma das narrativas por vir, já que, nenhuma narrativa, teoricamente, poderá fechá-lo definitivamente num sentido, numa interpretação.

Concluindo com a posição de Ricoeur neste domínio e apoiando-nos na análise de François Dosse (2012) diríamos que o autor 
foca a história através da textualidade narrativa que lhe dá corpo. É que a vertente narratológica nascida do linguistic turn deu toda a sua importância à explicação narrativa baseada na causalidade, isto é, no facto de haver na conjunção porque "duas funções distintas, a consecução e a consequência" (2012: 144). Por outro lado, existe uma proximidade de procedimentos entre o registo da historiografia e o da ficção no plano da estrutura narrativa. O que leva Ricoeur a concordar com estas posições é o facto de elas mostrarem como narrar é já explicar; mas não partilha a indistinção total com os narrativistas dado que estes abolem o fora de texto ou integram a história no texto infinito das suas remissões intertextuais, como se viu. É, portanto, o regime da veridicção que constitui o limite para além do qual Ricoeur não aceita a visão textualista. A noção de representância, introduzida atrás, constitui o ponto de resistência da referencialidade do texto da história (Dosse, 2012: 146). E, nessa medida, é sintoma da rejeição do textualismo, não cedendo, contudo, ao simplismo da referência pura. Elaborando a referencialidade no âmbito da configuração e da refiguração Ricoeur adota uma perspetiva conciliadora quer no modo de entender a ficção quer no modo de fazer história.

Que formas toma a narratividade hoje? Ricoeur admite que a contemporaneidade rompeu com essa configuração narrativa herdada de Aristóteles, tanto no caso da historiografia como no caso do romance como género englobante da ficção (1985: 387). E, para ele, este impasse não se coloca unicamente do lado das formas configuradoras mas está patente até numa resistência que se verifica nos atos refiguradores, nos limites da refiguração, como os denomina (1985: 387). Os limites da narrativa e a eclosão desses limites na crise das narrativas formarão, tal como o linguistic turn, uma autêntica viragem no pensamento que veio a ser denominado, em consequência, por pós-moderno. 


\section{A crise das narrativas}

Lyotard define a modernidade como uma atitude de pensamento e "ideologia científica" em que há sempre uma narrativa (heroica ou epopeica) a justificar e legitimar a ideia de progresso. As meta-narrativas que suportam tais enunciados são, por exemplo, a hermenêutica do sentido ou a emancipação do sujeito. Pelo contrário, a pós-modernidade desacredita as meta-narrativas. É a crise da filosofia metafísica. Ela localiza-se sensivelmente no pós-guerra, dado que a explosão tecnológica deslocou a questão da finalidade para a questão dos meios da ação.

Em O Inumano - considerações sobre o tempo, (1989: 72) apoiado numa análise da monadologia leibniziana, Lyotard propõe uma perspetiva temporal das sociedades capitalistas desenvolvidas em que tudo se joga numa previsão suportada pelas tecnologias digitais de globalização: os jogos de estratégia. Esses dispositivos permitem ao futuro antecipar-se no presente: "Garantias, confiança, segurança, são meios para neutralizar o caso como se fosse ocasional, para prever, digamos assim, o de-vir" (1989: 73).

Para Lyotard, já nos finais do século XX, as tecnologias eletrónicas iriam provocar um desafio às sociedades contemporâneas desenhando um outro tipo de narrativas, diverso daquele em que o acontecimento é acontecimento passado; tal desafio é o de controlar um processo ao "subordinar o presente ao que (ainda) chamamos 'futuro', já que nestas condições, o 'futuro' será completamente pré-determinado e o próprio presente deixará de se abrir sobre um 'após' incerto e contingente”. O princípio do capitalismo define-se por esta lógica da antecipação que iria hipotecar o futuro no presente das nossas vidas. A lógica da previsão veio a encaixar-se perfeitamente no dispositivo hipertextual e corporizando o enunciado premonitório de Lyotard: "nada mais pode acontecer no tempo t', a não ser a ocorrência programada no tempo t" ". O filósofo desenvolve o conceito dos jogos 
de estratégia, suportados pelas tecnologias digitais de globalização, concluindo: "Aí o futuro antecipa-se ao presente". Encontramos nesta operação generalizada de hipoteca do devir, uma fratura narrativa com o passado, ocorrido e delimitado no passado.

O sistema da economia capitalista sobrecodifica os possíveis em devir. O mesmo se passa na máquina narrativa do hipertexto: o utilizador-leitor tem a liberdade de executar todas as ligações possíveis, mas sempre no seio daquelas que foram pré-estabelecidas pelo sistema de sobrecodificação. O que quer dizer que o potencial de remissões que constitui a própria navegação do leitor está previamente programado, faz parte da própria máquina hipertextual. A liberdade situa-se tão-somente ao nível da atualização dessas conexões, dentro da virtualidade das possíveis. Lyotard prefigurou deste modo o desafio proposto pelas tecnologias de natureza eletrónica às sociedades contemporâneas: o de configurarem um outro tipo de narrativas, não as que encadeiam o acontecimento como acontecimento passado mas sim o de controlar um processo ao "subordinar o presente ao que (ainda) chamamos 'futuro', já que nestas condições, o 'futuro' será completamente pré-determinado e o próprio presente deixará de se abrir sobre um 'após' incerto e contingente" (1989: 72). Deparamonos, então, com a seguinte aporia: quanto mais condicionada é a abertura futura dos possíveis pela sua hipoteca presente, mais as narrativas (hipertextuais, entre outras) deslinearizam o tempo da sucessão, criando uma ilusão de infinitude dos possíveis narrativos. Então, do ponto de vista das grandes formações narrativas, aquilo que distingue as sociedades pré-modernas das sociedades modernas, é, segundo Lyotard, o facto de ambas produzirem e se alimentarem de macro-narrativas ou narrativas totalizantes mas em que, no primeiro caso, são míticas, e em que, no segundo, se fundamentam antes na razão e no saber científico, como instância legitimadora. A pós-modernidade, assistindo ao fim das macro-narrativas, definir-se-ia, por seu turno, pela dissolução do sentido por elas sustentado, dando 
lugar à disseminação de pequenas narrativas, de micro-narrativas constituintes de uma generalizada disseminação de sentidos e sua polemização.

Tendo em atenção a conceção de Lyotard, recorde-se que as narrativas se caracterizam por serem técnicas ou máquinas de ordenação do tempo, de encadeamento do acontecimento, de modo a, numa lógica de causalidade, ou, mais precisamente, numa lógica em que a contiguidade se funde ou coincide com a causalidade, "engendrar o sentido". O fim da narrativa passa por uma abolição dos critérios aristotélicos de unidade e de completude, como o relembra Paul Ricoeur (1984: 35), e esta crise precede o aparecimento tecnológico dos dispositivos digitais de hipertexto. A crise da composição narrativa advém da própria conceção de um real fragmentado, onde o fim não coincidirá jamais com a finalidade, onde a contingência do acontecimento deixa de poder ser subsumida pela ordem do necessário na narrativa.

Do ponto de vista da experiência literária, não é outro o fenómeno que eclode no romance como experiência-limite e que vem, ele também, marcar o aparecimento do pós-narrativo. Por isso, se escolhe como exemplificação, entre muitos outros textos indicadores desta rutura literária, L'Étranger de Albert Camus, publicado em 1942. Não propriamente para analisarmos a máquina narrativa em desagregação neste romance, mas para observarmos a confirmação dessa desagregação que leva Sartre a dedicar-lhe um texto crítico, compilado em Situations.

A propósito de Camus mas também do romancista americano, $\mathrm{J}$. Dos Passos, Sartre teoriza sobre a temporalidade narrativa. Seguindo a já estabelecida perspetiva, que encontramos em W. Benjamin, segundo a qual o romance inaugura já o fim da narrativa, defende aquele que a narrativa, ao contrário do romance, faz-se no passado. A narrativa tem uma prerrogativa, ela explica porque é causal. Ela dissimula, através da ordem cronológica, uma ordem causal. Todo 
o romance onde a ordem das coisas não se deixa agarrar pela ordem das causas não é narrativo, é caso destes autores, convocados por Sartre. Se há um défice de narrativa, se a máquina de articular causas e efeitos está desmanchada, então o que surge são acontecimentos, e "o acontecimento está a meio caminho entre o facto e a lei" (1947). Os acontecimentos, só por si, não produzem narrativa. Falta-lhes a mîse-en-intrigue que os configura em trama. Uma sucessão de presentes, como é o caso por exemplo em L'Étranger, não é uma narrativa. $\mathrm{O}$ romance não obedece à narrativa porque nele a causalidade está ausente. Não explica, descreve, afirma Sartre. Aliás, o absurdo como dimensão filosófica instala-se devido a essa total ausência de causalidade e de teleologia que constitui a vida. Em $O$ Mito de Sisifo, Camus declarara que o ideal do homem absurdo é essa sucessão de presentes onde a causalidade está totalmente abolida. Daí que o romance não seja nem possa ser narrativo. Porque até o romance exige um devir, uma continuidade temporal. Ora, L'Étranger é um romance onde "só o presente conta, o concreto" (1947: 108). A própria personagem, Meursault, "está lá, existe, e não podemos nem compreendê-la, nem julgá-la completamente; ela vive, enfim, e é a única densidade romanesca que a pode justificar aos nossos olhos" (1947: 110).

Em Hemingway encontra Sartre uma sucessão de presentes; há uma descontinuidade do tempo. Em L'Étranger há uma nova técnica (americana) já que se trata de dar uma "sucessão impensável e desordenada de presentes" (1947: 112). Comparando ambos os autores, conclui ele: "O que o nosso autor vai buscar a Hemingway é a descontinuidade das suas frases entrecortadas que se decalca sobre a descontinuidade do tempo". Em última análise, "cada frase é um presente" (1947: 117). Quer isto dizer que elas não estão organizadas mas "puramente justapostas". E mais: "evita-se quaisquer ligações causais que introduziriam na narrativa como um embrião de explicação e que poriam entre os instantes uma ordem diferente da 
pura sucessão" (1947: 118). Aquilo de que se trata nesta obra, pelo contrário, é de "uma tranquilizadora desordem de acasos". Camus, como muitos dos seus contemporâneos, "gosta[m] das coisas por si próprias e não quer[em] dilui-las no fluxo da duração", entende Sartre. Isto explicaria "por que o romancista prefere a uma narrativa organizada este cintilamento de pequenos brilhos sem amanhã em que cada um é uma volúpia”. Resulta daí a própria noção de absurdo, isto é: "nesse mundo que nos querem dar como absurdo e do qual se extirpou cuidadosamente a causalidade, o mais pequeno incidente tem peso" (1947: 119).

Por tudo isso, Sartre não poderá designá-lo como narrativo: “a narrativa explica e coordena ao mesmo tempo que retrata, substitui a ordem causal pelo encadeamento cronológico." Para Camus é um romance; no entanto, para Sartre, "o romance exige uma duração contínua, um devir, a presença manifesta da irreversibilidade do tempo." Não é o que acontece aqui: "nesta sucessão de presentes inertes que deixa entrever por baixo a economia mecânica de uma peça montada" (1947: 121).

A descontinuidade assumida é o que permite retirar um sentido metafísico à sequencialidade e fechamento narrativos. Sartre cita Malraux a este propósito: "o que há de trágico na morte é que ela transforma a vida em destino". A morte é o fechamento da vida, do tempo encadeado, causal.

Ora a conceção de destino, ela própria releva já da máquina narrativa. O destino é uma figura produzida por esta máquina de ordenar e dar sentido ao tempo. Se o trágico elabora a intriga nesta dimensão de destino, antecipando através do coro na tragédia grega a fatalidade do desenlace, o não poder não ser que é a pura negação da contingencialidade da vida, o destino, na narrativa, pode ser tomado como esse olhar, après coup, e cujo desenlace é explicado pela intriga. A figura do destino encontra causas e nexos no que está para trás, devolvendo-lhe essa transcendência metafísica que 
apazigua a disforia insuportável de uma vida, de um acontecimento, de um fenómeno natural. O destino é a figura narrativa que apela a um deus ex machina que tudo regula, independentemente da vontade e da ação humana. O destino é assim a figura por excelência da narrativa em que um destinador subjuga o sujeito, sujeitando-o a cumprir um desenlace mesmo se contra a sua vontade. A própria emergência deste sujeito subjugado ao soberano destino nos mostra como a máquina narrativa propaga a sua ideologia, possui as suas axiologias e organiza assim o sentido das vidas, em história.

A crise das narrativas é, portanto, mais do que uma transgressão de um código ou uma questão de caducidade dos géneros literários, uma forte perceção da sujeição do sujeito à máquina de ordenação causal.

Quando Mallarmé escreve: “Aucun coup de dés jamais n'abolira le hasard", para além da forma poética que inaugura ela própria toda uma poética, trata-se de uma palavra de ordem, de uma rutura, de um grito de libertação, da assunção, enfim, da contingência pura. Não daquela ideologia que vê ainda e sempre no acaso mais uma verificação da impossibilidade da pura coincidência, misturando e aplainando a contingência evencial da vida mas, antes, a declaração tremenda de que a contingência é a lei, de que o tempo são fragmentos dissociados, sem nexo, para os quais não há um qualquer sentido que os sustenha. A poética de Mallarmé é então uma filosofia do tempo, a condição abandonada de um sujeito ao puro acaso sem narrativa, sem origem nem telos. Na amargura da sua crueza contingencial. O puro acaso, sem coincidências. O silêncio da sua finitude.

Da epopeia ao romance contemporâneo, onde o carácter fragmentário e aleatório abandona as suas personagens numa desolação sem deus, eis, em toda a sua extensão, a assunção e queda do dispositivo narrativo e da sua função de produtor de sentido. O devir-biográfico, como movimento de configuração do sujeito, não desligado justamente das máquinas de representação, sejam elas narrativas 
textuais ou icónicas, é o movimento do sujeito moderno, garante da identidade do próprio.

Eis como a condição humana releva desse dispositivo que, no fundo, configura o humano tal como o conhecemos e a ele nos identificamos. Trata-se, em suma, de uma máquina de antropomorfização constante que põe em jogo a difícil conciliação entre o bios e o logos. Constatamos, assim, todo o processo histórico de constituição e construção da máquina antropomórfica que não é, senão, a máquina narrativa.

\section{REFERÊNCIAS BIBLIOGRÁFICAS}

Actes du Colloque de Cerisy-la-Salle (1991), Paul Ricoeur - les métamorphoses de la raison herméneutique. Paris: ed. Du Cerf.

ADAM, J. M. (2001) Les textes - types et prototypes. Paris: Nathan/HER.

AGOSTINHO (Sto) (2001) Confissões, trad. Arnaldo Espírito Santo et alii. Lisboa: INCM. ARISTÓteles (2011) La Poétique. Paris: Editions du Seuil.

BABO, M. A. (1993) A escrita do livro. Lisboa: Vega, coleção Passagens.

BenVeniste, E. (1966; 1974) Problèmes de Linguistique Générale, 1, 2. Paris: Gallimard.

CARR, D. (1991) "Epistémologie et Ontologie du Récit" in Paul Ricoeur - les métamorphoses de la raison herméneutique, Actes du Colloque de Cerisy-la-Salle. Paris: ed. Du Cerf.

DOSSE, F. (2012) Paul Ricoeur - un philosophe dans son siècle. Paris: Armand Colin. FOUCAULT, M., (1966) Les mots et les choses. Paris: Gallimard.

GILBERT, M. (2001) L'identité narrative - une reprise à partir de la pensée de Paul Ricoeur. Genève: Labor et Fides.

GREIMAS, A. J., e COURTÉS, J. (1979, 1986) Sémiotique - dictionnaire raisonné de la théorie du langage, tomos I e II. Paris: Hachette Université.

LAMIZET, B. (2006) Sémiotique de l'evénement. Chippenham: Hermes/Science; Lavoisier. 
LYOTARD, J.-F.(1989) O Inumano - considerações sobre o tempo. Lisboa: ed Estampa. MINK, L. O. (1970) "History and Fiction as Modes of Comprehension". in New Literary History, 1971, pp. 541-558.

REIS, C. e LOPES, A. C. M. (1991) Dicionário de narratologia, $3^{\circ}$ edição. Coimbra: Livraria Almedina.

RICOEUR, P. (1980) La fonction narrative. Paris: ISEO-ICP.

RICOEUR, P. Temps et Récit (1983, 1984, 1985), tomos I, II, III. Paris: Seuil.

RICOEUR, P. (1986) Du texte à l'action - essais d'herméneutique II. Paris: Seuil.

SARTRE, J.-P. (1947) Situations I. Paris: Gallimard.

SAUDAN, A. (1991) "Herméneutique et Sémiotique: intelligence narrative et rationalité narratologique". in Paul Ricoeur - les métamorphoses de la raison herméneutique, Actes du Colloque de Cerisy-la-Salle. Paris: ed. Du Cerf.

TIFFENEAU, D. (1980) La Narrativité. Paris: CNRS.

VEYNE, P., (1971) Comment on écrit l'histoire. Paris: Seuil. 